DOI: $10.30596 /$ persepsi.v\% vi\% i.4484

\title{
Persepsi Pria Muslim Terhadap Pengguna Pakaian Gamis
}

\author{
Suheri ${ }^{1^{*}}$ \\ Mahasiswa Program Pascasarjana Strata 3 UIN Medan, Sumatera Utara, Indonesia \\ Jalan IAIN No.1 Medan 20235 \\ ${ }^{*}$ Koresponden: suheri@gmail.com
}

\begin{abstract}
Abstrak
Penelitian ini bertujuan untuk mengetahui persepsi pria muslim yang menggunakan baju gamis di lingkungan XV dan XVIII di Kelurahan Mabar, Kecamatan Medan Deli. Mereka di antara para jamaah shalat yang ada di sebuah Masjid Subulussalam $\pm 40 \mathrm{~s} / \mathrm{d} 50$ dalam setiap shalat berjamaah menggunakan pakaian gamis tersebut. Metode penelitian ini menggunakan pendekatan kualitatif dan mengandalkan observasi dan wawancara mendalam dengan informan yang notabede pengguna pakaian gamis. Hasil penelitian ini menunjukkan bahwa pemakai pakaian gamis selalu tampil dengan percaya diri dan merasa nyaman dalam beribadah. Pengetahuan dan pendapat informan terhadap pemakai pakaian gamis adalah sebagai wujud dan bentuk pengetahuan yang dapat mencerminkan nilai sosial dalam rangka meningkatkan ketakwaan dan keimanan seseorang.
\end{abstract}

Kata Kunci: Persepsi, Baju Gamis, Nilai Sosial

\begin{abstract}
This study aims to determine the perceptions of Muslim men who wear a robe in the neighborhood of $X V$ and XVIII in Mabar Village, Medan Deli District. Those among the prayer worshipers at a Subulussalam Mosque are \pm 40 to 50 in each prayer congregation using the robe clothing. This research method uses a qualitative approach and relies on in-depth observation and interviews with informants who are not users of robe clothing. The results of this study indicate that robe wearers always appear confident and feel comfortable in worship. The knowledge and opinions of informants on robe wearers are as forms and forms of knowledge that can reflect social values in order to increase one's devotion andfaith.
\end{abstract}

Keywords: Perception, Clothing, Social Value

\section{PENDAHULUAN}

Setiap orang mempunyai sudut pandang yang berbeda terhadap sesuatu yang di pandang dan dilihatnya. Opini inilah yang membuat orang mempunyai sudut pandang yang berbeda-beda terhadap sesuatu yang di lihat dan di pandangnya. Orang memberikan makna terhadap apa yang terjadi di dalam dirinya sendiri atau lingkungan sekitarnya. Terkadang makna yang diberikan itu sangat jelas dan mudah di pahami orang lain namun terkadang makna itu sangat kabur tidak dapat di pahami dan bahkan bertentangan dengan makna sebelumnya. Dengan memahami teori komunikasi maka orang dapat menafs irkan peristiwa secara lebih fleksibel dan bermanfaat.

Pakaian gamis adalah pakaian yang dipakai oleh seorang muslim pria yaitu pakaian (kemeja) yang menjulur atau panjang ke bawah yang panjangnya tidak melebihi mata kaki atau yang lazim disebut secara umum adalah pakaian yang panjangnya antara betis dan mata kaki dan berukuran longgar. Pakaian gamis adalah pakaian kemeja biasa yang dipakai oleh kaum pria muslim yang berukuran panjang melebihi betis dan tidak sampai mata kaki

Pakaian gamis dipakai oleh sebagian pria muslim yang ada di lingkungan XV dan XVIII Kelurahan Mabar Kecamatan Medan Deli di antara mereka pemakaiannya adalah para jamaah shalat yang ada di sebuah Masjid Subulussalam \pm 40 s/d 50 dalam setiap sholat ber 
DOI: $10.30596 /$ persepsi.v\%vi\% i.4484

jama'ah dimana masjid ini yang terletak di antara Lingkungan XV dan XVIII Kelurahan Mabar Kecamatan Medan Deli.

Berdasarkan uraian di atas peneliti tertarik melakukan penelitian dengan judul "Persepsi Masyarakat Terhadap Pemakai Pakaian Gamis".

\section{Komunikasi Intrape rsonal}

Ilmu komunikasi merupakan landasan dasar dan ilmiah yang kedua setelah filsafat karena komunikasi terjadi pada diri manusia (intrapersonal) yang melibatkan proses sensansi, asosiasi, persepsi, memori dan berpikir. Seorang komunikator (enconder) melakukan proses komunikasi intrapersonal dengan seluruh energinya agar pesan yang di sampaikan kepada komunikan (decoder) dapat diterima dengan jelas, sehingga tercipta komunikasi yang efektif dan dapat merespon dan menimbulkan feed back yang baik dan positif. Komunikasi intrapersonal dapat di lakukan dengan beberapa hal meliputi :

\section{a. Sensasi}

Sensasi adalah proses penyerapan informasi (energi/stimulus) yang datang dari luar melalui pancaindra. Sensasi berasal dari kata sense, artinya alat pengindraan, yang menghubungkan organisme dengan lingkungannya. Menurut Dennis Coon, dalam Benyamin B. Wolman (1973: 343) "Sensasi adalah pengalaman elementer yang segera dan tidak memerlukan penguraian verbal, simbolis atau konseptual, terutama berhubungan dengan kegiatan alat indra".

\section{b. Asosiasi}

Asosiasi adalah pengalaman dan kepribadian yang mempengaruhi proses sensasi, asosiasipun dapat diartikan serta di maknakan sebagai sesuatu predisposisi yang meliputi ruang lingkup pengetahuan dan pengalaman untuk menemukan dan memahami suatu kepribadian (personality).

\section{c. Persepsi}

Persepsi merupakan salah satu aspek psikologis yang penting bagi manusia dalam merespon kehadiran berbagai aspek dan gejala di sekitarnya. Persepsi mengandung pengertian yang sangat luas, menyangkut intern dan ekstern. Berbagai ahli telah memberikan definisikan yang beragam tentang persepsi, walaupun pada prinsipnya mengandung makna yang sama. Menurut kamus besar bahasa Indonesia, persepsi adalah tanggapan (penerimaan) langsung dari sesuatu. Proses seseorang mengetahui beberapa hal melalui panca inderanya.

\section{Gamis Dalam Komunikasi Non Verbal}

George Herbert Mead di pandang sebagai pembangun paham interaksi simbolik. Ia mengajarkan bahwa makna muncul sebagai hasil interaksi di antara manusia, baik secara verbal maupun non verbal. Melalui aksi dan respon yang terjadi kita memberikan makna ke dalam kata-kata atau tindakan, dan karenanya kita dapat memahami suatu peristiwa dengan cara-cara tertentu.

Pakaian panjang atau gamis yang di pakai oleh seseorang adalah suatu tanda atau simbol nonverbal yang mempunyai makna dan arti tersendiri oleh pe makainya, sehing ga para masyarakat mempunyai penilaian dan persepsi tersendiri terhadap pemakainya.

Menurut paham interaksi simbolik, individu berinteraksi dengan individu lainya sehingga menghasilkan suatu ide tertentu mengenai diri yang berupa menjawab pertanyaan siapakah anda sebagai manusia? Manford Kuhn menempatkan peran diri sebagai pusat kehidupan sosial dan pemakai pakaian gamis adalah mempunyai ciri tersendiri dalam penampilannya bermasyarakat.

Suatu objek dapat berupa aspek tertentu dari realita individu, apakah itu suatu benda, kualitas, penampilan yang berbeda atau suatu peristiwa dalam suatu keadaan tertentu. Satusatunya syarat agar sesuatu menjadi objek adalah dengan cara memberinya nama dan 
DOI: $10.30596 /$ persepsi.v\% vi\% i.4484

menunjukkanya secara simbolik yang terjadi dalam masyarakat dan mempunyai totalitas dari objek adalah penting dalam menyampaikan suatu makna dan nama objek.

Ketika seseorang membuat suatu keputusan bagaimana bertingkalaku terhadap suatu objek sosial. Maka orang akan menciptakan suatu tindakan yang terencana (a plan of action) yang kemudian di pandu dan diarahkan. Misalnya seseorang yang ingin melakukan suatu simbol berupa gamis berukuran panjang, maka dia akan menyusun suatu rencana yang positif dan jika nilai positif yang lebih dominan, maka dia akan membuat gamis berukuran panjang, namun sebaliknya apabila dia berpikiran negatif atau didominasi pikiran negatif, maka dia tidak akan membuat gamis berukuran panjang.

\section{Teori Interaksi Simbolik}

Interaksi Simbolik bisa dikategorikan sebagai salah satu rumpun teori fenomenologi dan sekaligus pula sebagai suatu model atau metode yang berkarakteristik post-positivistik. Dalam dunia metode penelitian, teori dan perspektif interaksionis simbolik kerap digolongkan sebagai penelitian yang bersifat kualitatif. Secara teoritis, interaksi simbolik telah merasuk ke dalam subjek begitu dalam sehingga terbuka ruang untuk mencapai penafsiran-penafsiran boleh subjek terhadap hal-hal di luar dirinya, terutama data sekitarnya dengan keputusan untuk bertindak atau memilih reaksi.

Ruang bukan sekedar fakta fisik melainkan ruang bisa ju ga memiliki makna simbolik tertentu ketika ruang itu diinteraksikan dengan pelaku-pelaku sehingga perilaku manusia harus dilihat sebagai proses yang memungkinkan manusia membentuk dan mengatur perilaku mereka dengan mempertimbangkan harapan orang la in yang menja di mitra interaksi mereka.

Penelitian ini menggunakan teori interaksi simbolik sebagai dasar pijakan untuk memahami perilaku manusia ketika berhadapan dengan simbol-simbol karena pada dasarnya makna atas simbol-simbol adalah produk interaksi sosial, karena makna tidak melekat pada objek melainkan dine gosiasikan me la lui pe nggunaan bahasa.

Pemaknaan terhadap simbol-simbol yang dipertukarkan antar pelaku komunikasi tentu saja tidak bersifat langsung dan pada saat itu juga, akan tetapi membutuhkan pemahaman yang re latif sama sehingga kerangka pengalaman dan pengetahuan para pelaku akan menentukan pada tingkat pendalaman makna dengan demikian pemahaman terhadap ruang belajar tentu saja dipengaruhi faktor usia, latar belakang pendidikan dan mobilitas siswa dalam berinteraksi dengan lingkungan belajar yang lain.

Paham mengenai interaksi simbolis (Symbolic Interactionisme) adalah suatu cara berfikir menge nai pikiran diri dan masyarakat yang telah banyak memberi kontribusi kepada tradisi sosiokultural dalam membangun teori komunikasi dengan menggunakan berbagai fondasi dan sosiologi. Pemahaman ini interaksi simbolik memfokuskan pada cara-cara yang digunakan manusia untuk membentuk makna struktur masyarakat melalui percakapan.

\section{Teori Simbol}

Teori simbol yang diciptakan Susanne Langer adalah teori terkenal dan dinilai bermanfaat karena menge mukakan sejumlah konsep dan istilah yang biasa digunakan dalam ilmu komunikasi. Sedemikian rupa, teori ini memberikan semacam standar atau tolak ukur bagi tradisi sistematika didalam studi ilmu komunikasi. Langer yang secara ahli ilmu filsafat, karena simbol menjadi penyebab dari semua pengetahuan dan pengertian yang dimiliki manusia. Menurut Langer, kehidupan binatang diatur oleh perasaan (feeling), tetapi perasaan manusia diperantari sejumlah konsep, simbolik dan bahasa binatang memberikan respon terhadap tanda, tetapi manusia membutuhkan lebih dari sekedar tanda, manusia 
membutuhkan simbol.

Suatu "tanda" (Sign) adalah suatu stimulus yang menandai kehadiran suatu yang lain. Jika seseorang melatih kucing peliharaannya untuk duduk ketika ia mengatakan "duduk!" maka itu adalah tanda bagi kucing untuk duduk. Dengan demikian, suatu tanda berhubungan erat dengan maksud tindakan yang sebenarnya.(Actual Signified Action).

Simbol, sebaliknya bekerja dengan cara yang lebih kompleks yaitu dengan membolehkan seseorang untuk berpikir mengenai suatu yang terpisah dari kehadiran secara suatu tanda, dengan kata lain, simbol adalah "suatu instrumen pikiran" (instrument of thought). Anjing tidak perlu berfikir lama dalam prosesnya untuk duduk setelah menerima perintah "duduk!".Namun manusia membutuhkan waktu untuk memikirkan suatu simbol dan jika anda mendengar seseorang berkata, "saya sayang kamu" maka di benak anda muncul berbagai makna, dan respon yang anda berikan menjadi sangat kaya dan kompleks yang penuh berbagai persepsi. Simbol menjadi yang sentral dalam kehidupan menusia. Manusia mempunyai kemampuan untuk memiliki dan menggunakan simbol yang sama pentingnya dengan kebutuhan terhadap simbol yang sama pentingnya dengan kebutuhan terhadap makan atau tidur. Kita mengarahkan dunia fisik dan sosial kita melalui simbol dan maknanya.

Langer memandang "makna" sebagai suatu hubungan yang kompleks diatara simbol, objek dan orang. Aspek logis adalah hubungan antara symbol dan referenya. Yang oleh Langer dinamakan "denotasi" (denotation). Adapun aspek atau mana psikologi adalah hubungan antara simbol dan orang, yang disebut "konotasi" (conotation). Jika anda mengatakan, jaket adalah busana yang di pakai oleh seseorang pada suasana dingin atau hujan "jaket" yang merupakan makna denotasi. Sebaliknya jika anda mengatakan "saya tidak suka memakai jaket kerena saya sering merasa gerah, dan juga kota tempat saya psikologisnya atau konotasinya yang merupakan hubungan yang lebih komplek antara diri anda dan simbol bersangkutan.

\section{Teori Bahasa}

Studi tentang Bahasa sangat di pengaruhi oleh semiotika dan sebaliknya dan karena itu adalah penting bagi kita untuk mengetahui mengenai struktur bahasa karena struktur bahasa mengetahui pesan. Ferdinand de sausure, pendiri struktur linguistik modern yang berjasa memberikan sumbangan besar pada tradisi struktural dalam ilmu komunikasi, mengajarkan bahwa "tanda" (sign) termasuk bahasa, adalah bersifat acak (arbit). Ia mengatakan bahasa yang berbeda menggunakan kata-kata yang berbeda untuk menunjukan hal yang sama, dan bahwa biasanya tidak ada hubungan fisik antara suatu kata dengan referenya. Karena itu, tanda merupakan kesepakatan yang di arahkan oleh aturan (sign are convention governed by rule).

Menurut Saussure, kunci untuk memahami structure dan system bahasa adalah perbedaan (difference). Satu bentuk tata bahasa juga berbeda dengan tata bahasa lainnya. Sistem perbedaan ini membentuk struktur bahasa, baik dalam bahasa percakapan maupun bahasa tulisan. Bahwa pengalaman manusia tentang dunia di tentukan oleh bahasa.

\section{Teori Tanda Non- Ve rbal}

Para ahli komunikasi mengakui bahwa bahasa dan perilaku manusia seringkali tidak dapat "bekerja sama" dalam menyampaikan pesan, dan karenanya "teori tanda nonverbal" (Theories of nonverbal signs) atau komunikasi nonverbal merupakan elemen penting dalam tradisi semiotika. Namun apa yang di maksud atau apa batasan komunikasi nonverbal sungguh sangatlah luas sebagai mana dikemukakan Randal Harris on berikut ini : "Istilah komunikasi nonverbal telah digunakan pada berbagai peristiwa sehingga mala membingungkan. Segala hal mulai dari wilayah hewan hingga protokoler diplomatik dari ekspresi wajah hingga gerakan otot. Dari perasaan di dalam diri yang tidak dapat di ungkapkan hingga bangunan monumen luar ruang milik publik. 
DOI: $10.30596 /$ persepsi.v\% vi\% i.4484

\section{a. Pengertian Mas yarakat}

Di dalam ilmu sosiologi terdapat satu susunan kata dengan istilah masyarakat. Istilah ini sering kita gunakan dalam percakapan sehari - hari, dalam pidato-pidato, majalahmajalah, surat kabar, tetapi bukan merupakan suatu kata yang mudah untuk dijelaskan sebagaimana dengan dugaan kita semua. Meskipun harus diakui adanya kemungkinan istilah sehingga ditangkap dan cepat menimbulkan suatu pengertian yang tidak mudah untuk diuraikan.

Menurut Budiarjo (2008:46) masyarakat adalah keseluruhan antara hubungan antar manusia. Robert M. McIver dalam Budiardjo (2008:46) mengatakan masyarakat adalah suatu sistem hubungan yang ditata. Biasanya anggota-anggota masyarakat menghuni suatu wilayah geografis yang mempunyai kebudayaan-kebudayaan dan lembaga-lembaga yang kira-kira sama.

Syarbaini (2004:10) berpendapat bahwa secara umum pengertian masyrakat adalah "sejumlah manusia yang hidup dalam suatu hubungan dalam kurun waktu yang cukup lama sehingga melahirkan budaya dengan satu kesatuan kriteria dalam memilih system hidup bersama".

Selo Soemardjan (2006:10) menyatakan bahwa masyarakat adalah "orang-orang yang hidup bersama yang menghasilkan kebudayaan".

Mustofa (2008:202) mengemukakan bahwa masyarakat adalah "kesatuan hidup manusia yang berinteraksi menurut sistem adat istiadat tertentu yang bersifat terus menerus dan terkait oleh rasa dan identitas yang sama".

Dari pengertian diatas maka dapat disimpulkan bahwa masyarakat adalah kumpulankumpulan manusia untuk melangsungkan kelangsungan kehidupannya, untuk bertahan hidup dengan memenuhi segala kebutuhan-kebutuhannya dan menggunakan akal pikirannya untuk mengorganisasikan dirinya, sehingga didalam organisasi itu timbul aturan-aturan atau undang-undang yang mengatur mereka untuk menuju kepada kepentingan dan tujuan bersama.

Menurut Marion Levy dalam Sunarto (2004: 56) mengemukakan empat kriteria yang perlu dipenuhi agar suatu kelompok dapat disebut masyarakat yaitu :

1) Kemampuan bertahan melebihi masa hidup seseorang individu.

2) Rekrutmen seluruh atau sebagian anggota melalui reproduksi.

3) Kesetiaan pada suatu "sistem tindakan utama bersama".

\section{b. Jenis - Jenis Mas yarakat}

Sukanto (2002:67) menyatakan bahwa jenis-jenis masyarakat terdiri dari:

(1) Mayarakat Sederhana

Adalah masyarakat yang hubungan kekeluargaannya sangat kuat, organisasi sosial didengarkan adat istiadat, hukum yang berlaku tidak tertulis, tingkat buta huruf tinggi

(2) Masyarakat Madya

Adalah hubungan keluarga sangat kuat, tetapi hubungan dalam masyarakat sudah luntur

(3) Masyarakat Modern

Adalah hubungan antar manusia terutama didasarkan atas kepentingankepentingan bersama.

Menurut Kosim (1997:79) masyarakat terdiri dan dua yaitu masyarakat perkotaan dan masyarakat pedesaan.

a. Masyarakat pedesaan adalah masyarakat yang lebih menekankan hubungan nya dengan perasaan, sayang, cinta, kesetiaan, kemesraan, me mentingkan kebersamaan.

b. Masyarakat perkotaan adalah masyarakat yang gaya hidupnya cenderung bersifat individualisme dan sebagian lagi dapat juga disebut desa karena masih memperlihatkan gaya hidup kolektif. 
DOI: $10.30596 /$ persepsi.v\%vi\% i.4484

\section{METODE}

Penelitian yang dilakukan dalam penelitian ini adalah jenis penelitian deskriptif pendekatan kualitatif yang terdiri dari satu variable yaitu : persepsi masyarakat terhadap pemakai pakain gamis, sedangkan lokasi penelitian di lakukan pada masyarakat 2 lingkungan (XV dan XVIII) Kelurahan Mabar Kecamatan Medan Deli yang dikonsentrasikan di Masjid Subulussalam

Menurut Rahmat (1984: 24) bahwa deskriptif kualitatif adalah metode yang bertujuan menggambarkan secara sistematis fakta atau karakteristik informan tertentu secara faktual dan cermat. Jadi hal ini hanya bagaimana persepsi masyarakat terhadap pemakai pakaian gamis. Nawawi (1987: 63). Deskriptif adalah pemecahan masalah yang diselidiki dengan menggambarkan atau melukiskan subjek dan objek peneliti (masyakarat, pe makai gamis dan lain-lain) pada saat sekarang berdasarkan fakta yang tampak atau sebagaimana adanya.

Dengan melihat berbagai kutipan di atas, maka hal yang akan di ungkapkan atau dideskriptifkan dari hasil penelitian ini adalah apa-apa saja dan bagaimana persepsi masyarakat tersebut terhadap pemakai pakaian panjang (gamis) yang kesemuanya itu tidak terlepas dari adanya penelitian ke lokasi penelitian.

Berkaitan dengan perolehan data yang diuangkapkan sebagaimana perolehan dari hasil penetitian ini adalah lewat pelaksanaan pengumpulan data berupa persiapan awal, memperhatikan dan memantau lokasi penelitian dan pengumpulan data di lapangan.

Dalam kaitannya Bahasa Rakhmat dan Nawawi yang kedua-duanya membahas karakteristik informan tertentu secara factual serta membahas dari persiapan awal dan pengumpulan data di lapangan hingga hasil dari penelitian tersebut.

Untuk mendapatkan informasi yang dianggap dapat mewakili keseluruhan informan, maka penelitian menggunakan kriteria sebagai berikut :

1. Masyarakat yang mengetahui secara langsung mengenai pemakai pakaian gamis

2. Masyarakat yang selalu melihat langsung para pemakai pakaian gamis di Masjid Subulussalam dan sekitarnya

3. Masyarakat yang pernah berkomunikasi langsung dengan para pe makai pakaian gamis (teman, tetangga atau saudara)

\section{HASIL DAN PEMBAHASAN}

Berdasarkan hasil penelitian dan penelusuran peneliti di lapangan tentang Persepsi Masyarakat Terhadap Pemakai Pakaian Gamis (Studi Deskriptif Persepsi Masyarakat Lingkungan XV dan XIII Kelurahan Mabar Kecamatan Medan Deli) bahwa pe makai pakaian gamis selalu tampil dengan percaya diri dan merasa nyaman da lam beribadah."

Beberapa informan terhadap pemakai pakaian gamis mempunyai nilai sama antara satu informan dengan informan lainnya, hal ini terlihat dalam beberapa pendapat yang dapat dihimpun peneliti, dalam keadaan pada awalnya informan belum mengetahui pers is pakaian gamis hingga akhirnya informan mengetahui persis pakaian gamis yang selalu dipakai orang ketika melaksanakan ibadah shalat. Pengetahuan dan pendapat informan terhadap pemakai pakaian gamis adalah sebagai wujud dan be ntuk pengetahuan yang dapat mencerminkan nilai sosial dalam rangka meningkatkan ketakwaan dan keimanan seseorang, jika pakaian gamis dipandang dan dianggapi secara positif oleh masyarakat maka dapat dipastikan bahwa para pemakai pakaian gamis adalah salah satu ciri ketakwaan seseorang akan suatu ajaran agamanya, sangatlah pas bila pakaian gamis dikaitkan dengan rasa keimanan seseorang dalam rangka mengaplikasikan serta mengekspresikan suatu ilmu yang diterimanya yang dituangkan dalam bentuk berpakaian gamis dalam melaksanakan ibadah shalat.

Keberadaan pakaian gamis selama ini masih dianggap hal yang masih aneh atau asing. Adapun pemakai pakaian yang di maksud adalah pria muslim. Karena secara umum 
bahwa pakaian gamis adalah jenis pakaian pria yang belum di sosialisasikan oleh pe makainya secara terang-terangan, namun para pemakainya secara bahasa sudah memberikan contoh pakaian gamis lewat bahasa penampilan dan gaya berpakaian secara islami.

Dalam berbagai hal dan berbagai kesempatan bahwa dalam berpakaian mempunyai maksud dan tujuan tersendiri, serta sebuah model akan di menunjukan karekteristik seseorang, warna dan corak dalam sebuah pakaian juga memberikan arti tersendiri sehingga dalam kaitannya bahasa komunikasi nonverbal segala sesuatu bentuk dan jenis yang di pakainya memberikan lambang dan makna tersendiri, selaras dengan pakai gamis yang identik dengan pemahaman keagamaan dan keyakinan seseorang maka hal yang muncul adalah konsep dan nilai ketaqwaan dan keimanan seseorang.

Kecenderungan sebagian masyarakat Lingkungan XV dan XIII Kelurahan Mabar dan Kecamatan Medan Deli dalam berpakaian dan berpenampilan khususnya masyarakat yang melaksanakan ibadah sholat di masjid Subullussalam, yaitu mengikuti trend dan kekinikinian. Seperti trend kebanyakan orang memakai batik. Sebatas pakaian yang dipakai tidak melanggar norma-norma kehidupan masyarakat dan beragama tentu hal ini sah-sah saja dan wajar-wajar saja, disamping pakaian gamis sebagai wujud dan bentuk ketakwaan dan keimanan terhadap pemakainya, tentu eksistensi dan keberadaan pakaian gamis perlu dijaga dan di budayakan lewat berbagai macam bentuk sosialisasi.

\section{Pakaian Gamis Se bagai Budaya Berpakaian}

Secara pasti belum ada dan diketahui bahwa budaya bangsa Indonesia mengajarkan dan mencontohkan pakaian gamis, namun dapat diperkirakan munculnya pakaian gamis seiring dengan berkembangan Islam dan budaya berpakaian secara umum masyarakat yang mayoritas Islam karena dalam konteks ajaran Islam bahwa berpakaian harus menutupi aurat. Dalam hal ini salah satunya yaitu pakaian gamis. Sementara pada masyarakat Arab pakaian gamis adalah suatu pakaian yang di pakai atas dasar budaya dan tradisi yang ada dalam masyarakat.

\section{Pakaian Gamis Sebagai Seni Dan Keindahan}

Memakai pakaian gamis untuk seni dan keindahan terhadap pemakainya adalah motivasi yang kuat yang muncul dari hati dan rasa keindahan dalam makna berpakaian kekuatan dan motivasi inilah sehingga para pemakai pakaian gamis kian bertambah banyak. Informan dari berbagai informan menguatkan akan para pemakai pakaian gamis yang ada di Lingkungan XV dan XIII Kelurahan Mabar Kecamatan Medan Deli. Pakaian gamis hampir dapat disamakan ibarat seseorang me makai perlengkapan asesoris pelengkap gaya berpakaian dalam berpenampilan. Menempatkan pakaian gamis sebagai bentuk keindahan terhadap pemakainya adalah sebagai salah saru bentuk seni dan keindahan.

Keindahan dalam berpakaian dapat diciptakan lewat berbagai upaya dan usaha para pemakainya sendiri. Motif melambangkan suatu seni. Seni itulah yang akan melahirkan suatu keindahan pakaian gamis tidak hanya dipakai oleh para orang tua dan kalangan remaja namun pakaian gamis di pakai juga oleh kalangan anak-anak jika beberap kalangan sudah memakai pakaian gamis maka secara keseluruhan pakaian gamis tidak hanya sekedar pakaian atas dasar takwa dan keindahan, perubahan sistem dan nilai sosial akan mempengaruhi cara orang atau masyarakat dalam berpakaian. Pakaian gamis pakaian gamis akan terus manjadi suatu simbol ketaatan seseorang terhadap nilai-nilai ketakwaan dan keimanan.

Masyarakat mulai memahami pakaian gamis sebagai suatu simbol-simbol eks presi dan sebagainya sehingga pe makai pakaian gamis lebih cenderung ke arah yang positif.

\section{Pakaian Gamis Sebagai Lambang Identitas}


Selain pakaian gamis sebagai bentuk seni dan model dalam berpakaian secara islami, maka pakaian gamis pun menjadi suatu lambang dan identitas dalam pola berpakaian secara is lami. Banyak orang menjadikan pakaian gamis sebagai lambang ke islaman dan sebagai identitas orang bertakwa dan beriman kepada Allah Swt, walaupun sebenarnya tidak ada simbol khusus dalam berpakaian dan tidak ada kumpulan ataupun komunikasi khususnya dalam berpakaian gamis tersebut.

Konsep gamis sebagai suatu bentuk lambang yang merupakan ketakwaan dan keimanan, maka pakaian gamis memiliki nilai tambahan yang menjadi suatu bentuk kebersamaan makna dalam menjaga kewibawaan dan identitas. Pakaian gamis belum dijadikan label asasi yang cukup kuat yang dijadikan sumber kekuatan dalam memaknai sebagai pakaian ketakwaan para pemakai pakaian gamis mempunyai nilai kebersamaan namun berpakaian gamis bukan suatu keharusan dalam setiap aktivitas, namun di sisi lain adanya suatu nilai semangat para pemakai pakaian gamis untuk saling meningkatkan rasa persaudaraan dan rasa silahturahmi.

Ketika gamis menjadi suatu pedoman dalam berpakaian yang sopan dan menjadi lambang identitas rasa ketakwaan dan keimanan seseorang, maka keharusan dalam berpakaian secara sunnah akan mampu memberikan warna kehidupan sosial yang mengarah pada tujuan berpakaian yang diajarkan suatu ajaran agama yang lebih baik.

\section{Pakaian Gamis Sebagai Alat Komunikasi}

Pakaian gamis adalah pakaian yang di jadikan para pemakainya untuk sarana ibadah shalat dan aktivitas-aktivitas lainnya. Pakaian gamis dapat di artikan dalam berbagai pola pikir secara sederhana. Di satu sisi dapat diartikan sebagai a lat komunikasi secara nonverbal dan lewat berpenampilan secara simbolik dan dapat dijadikan suatu tindakan komunikasi yang dilakukan secara terus menerus.

Pada awalnya setiap individu mempunyai cara tersendiri dalam melakukan segala bentuk komunikasi berbagai bentuk dan model pakaian gamis mencerminkan beberapa simbol komunikasi.

Keterkaitan dalam suatu bentuk dan model dalam memakai pakaian gamis menjadi nilai tersendiri dan kode yang mempunyai makna berbeda, walaupun di lihat secara umum sama dan tidak menunjukan perbedaan yang sangat tampak. Berbagai ukuran dan warna serta model akan menggungkapkan komunikasi tersendiri serta pengaruh.

Pandangan masyarakat dalam menyampaikan pesan komunikasi melalui cara berpakaian akan memberikan makna yang dapat menunjukkan nilai kebersamaan.

\section{Pengenalan}

- Gamis dengan corak bergar is panjang

Gamis model seperti ini biasanya dipakai dan seiring digunakan para jamaah sholat yang mempunyai pemahaman Salafi. Kemudian para pemakainya sering mengidentikkan pakaian gamis sebagai suatu simbol kebanyakan yang dipakai kalangan jamaah itu sendiri dan para ustadnya yang selalu eksis dengan pemahaman As-Sunnah dan biasanya dengan ukuran yang cukup longgar serta panjang standar di bawah lutut dan di atas mata kaki.

- Gamis dengan model lengan pendek

Model gamis seperti ini biasanya dipakai dan sering digunakan jamaah sholat yang mempunyai pemahaman Ikhwanul Mus limin dan selanjutnya para pemakainya sering identik sebagai wujud kebebasan dalam memakai pakaian gamis sebatas menutup aurat dalam melaksanakan ibadah shalat. Namun terkadang para jamaah pemahaman ini sering juga menambahkan kain sarung dibagian bawahnya.

Pada tatanan dan sistem sosial sebagai wujud kebersamaan dan masyarakat, para jamaah tidak mempersoalkan dari jenis gamis yang dipakai para jamaah yang mempunyai 
pemahaman agama masing-masing. Nilai kebersamaan yang diwujudkan dalam shalat berjamaah di masjid adalah yang paling utama tanpa melihat dan membedakan perbedaanperbedaan dan pemahaman-pemahaman yang ada. Gamis sebagai pakaian ungkapan keimanan dan ketaqwaan terhadap ajaran agama Islam yang notabene sebagai suatu ajaran yang murni yang diajarkan Rasulullah yang disampaikan para sahabatnya dan orang-orang istiqomah pa da ajaran Islam dalam konteks pakaian gamis dalam pelaksanaan ibadah sha lat.

Ketika wujud keimanan diakomodir lewat cara berpakaian maka nilai-nilai social akan terwujud lebih nyata dan lebih jelas sehingga gamis dipandang sebagai konsep yang menjadi tolak ukur bagi para pemakainya. Hal ini tentu agar senantiasa pakaian gamis sebagai alat komunikasi non verbal yang dipandang masyarakat sebagai alat pemersatu dalam suatu ibadah shalat dan ibadah lainnya. Dengan simbol pakaian gamis, maka akan lebih mengkikis perbedaan-perbedaan yang ada secara internal dan eksternal (baik di dalam maupun di luar Masjid Subulussalam tersebut).

Gamis awalnya dipandang masyarakat Lingkungan XV dan XIII Kelurahan Mabar, Kecamatan Medan Deli suatu bentuk pakaian yang aneh yang ada di lingkungan tersebut. Hal ini terekam dari informasi beberapa informan ketika peneliti melakukan wawancara secara langsung, sehingga berbagai prasangka terhadap pemakai pakaian gamis muncul namun dapat dikikis dengan berbagai keterangan dan semangkin bertambahnya para pemakai pakaian gamis.

Prasangka dan persepsi masyarakat terhadap pe makai pakaian gamis pada akhirnya menjadi bentuk persepsi yang positif dan ditanggapi secara baik. Aneka ragam dan model yang dipakai oleh pemakai pakaian gamis menjadikan sebuah trend dan model dalam berpakaian gamis. Apalagi pakaian gamis dipakai secara maknawi dan tradisi masyarakat setempat dan orang-orang yang meminatinya, seperti misalnya seorang yang memakai pakaian gamis dengan makna kebersamaan dan berpakaian sholat sehingga ditemui sustu bentuk komunikasi nonverbal dengan simbol kebersamaan dalam berpakaian gamis.

Gamis dengan ditambah memakai sorban ini memberikan makna dan simbol kelengkapan dalam melaksanakan ibadah sholat yakni yang tergambar sebagai rasa kesopanan dalam beribadah kepada yang maha kuasa.

Gamis dengan ditambah me makai kopiah ini memberikan makna dan simbol kelengkapan dalam melaksanakan berbagai macam bentuk keagamaan terutama dalam melaksanakan ibadah shalat.

Gamis dengan ditambah memakai kain sarung pada bagian bawah. Ini memberikan makna dan simbol sebagai pakaian longgar dan tidak tergantung bagian tubuh sehingga tidak terpandang bagian belakang tubuh atau bentuk bagian be lakang tubuh. Gamis dengan warna polos (satu warna) ini melambangkan dan menggambarkan agar senantiasa bagi orang lain yang melihatnya tidak mengganggu konsentrasi (khusyuk) dalam melaksanakan ibadah shalat.

Masyarakat dalam penelitian ini mengaku dan memberikan keterangan tentang pemakai pakaian gamis sangat positif dan menanggapinya secara baik, karena para pemakai pakaian gamis adalah orang rajin melaksanakan ibadah shalat secara berjamaah di masjid. Untuk itu secara langsung maupun tidak langsung bahwa informan menilai pakaian gamis adalah suatu bentuk pakaian sopan menutup aurat seorang laki-laki. Kebanyakan para pemakai pakaian gamis adalah orang-orang yang hendak mendirikan shalat di masjid. Adapun gamis dan model yang dipakai pun berbeda-beda dalam bentuk dan ukuran yang sesuai dengan ukuran tubuhnya.

Pakaian gamis dengan ukuran panjang hampir mata kaki saat sekarang ini menjadi trend dan merupakan yang di gemari para pemakainya. Perkembangan pakaian gamis menjadi suatu budaya dan kebiasaan masyarakat ketika hendak melaksanakan ibadah shalat. 
Pengertian pakaian gamis dalam masyarakat sudah menyentuh pada aspek kebersamaan dalam memaknai konsep dasar pemahaman agama.

Beberapa pandangan masyarakat terhadap pemakai pakaian gamis sangat miring. Hal ini terjadi dengan adanya isu-isu tindakan kriminal seperti gerakan sparatis yang mengatas namakan kelompok-kelompok islam tertentu. Oleh karena itu tidaklah mengherankan jika is u-isu pihak-pihak tertentu untuk memberikan kekacauan dalam komunikasi secara nonverbal lewat cara berpakaian mendapat isu miring dan kecaman yang salah.

\section{Tanggapan}

Dalam beberapa keterangan yang diperoleh dari masyarakat tentang persepsi masyarakat terhadap pemakai pakaian gamis, ada beberapa hal yang perlu di tanggapi secara menyeluruh, di antaranya dari segi budaya bahwa pakaian gamis sebenarnya adalah bukan budaya atau milik masyarakat Indonesia, namun dipandang dari sisi agama gamis adalah pakaian yang di ajarkan dalam bentuk pakaian sunnah untuk melaksanakan ibadah shalat. Pakaian gamis dan persepsi masyarakat dapat ditanggapi secara positif dan dapat dijadikan suatu metode dalam berpakaian dan berpenampilan.

Pemahaman masyarakat terhadap pakaian gamis terus berkembang sejalan dengan pengetahuan yang dimiliki dan berkembang semakin banyaknya para pemakai pakaian gamis mengalami berbagai macam penilaian, namun perkembangan pemakai pakaian gamis terus kian bertambah. Beberapa kelompok masyarakat yang menggunakan berbagai teknik untuk mensosialisasikan pakaian gamis dalam bentuk keserasian dan model yang dikombinasikan dengan tambahan kain batik sehingga dapat memperindah model gamis.

Sistem sosial yang ada di Lingkungan XV dan XIII Kelurahan Mabar Kecamatan Medan Deli menggambarkan suatu keadaan masyarakat yang saling menghormati dan saling menghargai setiap pendapat dan gagasan yang muncul dan berkembang. Namun dengan konsep dasar pola berpakaian dalam pelaksanaan ibadah sholat ada sebagian masyarakat yang memakai pakain gamis. Prilaku dan perbuatan seseorang terkadang tidak mempunyai nilai yang sama, seperti halnya ketika seseorang memakai pakaian gamis, tidak semua yang memakai pakaian gamis mempunyai sistem sosial dan kesabaran yang sama. Jadi setiap mengenal diri kita terkadang setelah adanya penilaian dari orang lain baru kita kenal dan memahami diri kita. Yang menjadi cermin pada diri kita sebenarnya adalah penilaian orang lain. Respons dan tanggapan orang lain yang menjadi diri kita sendiri.

Sikap toleransi masyarakat Indonesia masih dibilang tinggi, sehingga dalam menentukan sesuatu sikap terhadap orang lain masih menerima apa adanya. Indonesia adalah masyarakat yang mayoritas muslim dan barang pasti setiap prilaku dan tindakan serta perbuatannya masih berorientasi pada ajaran agama Islam, seperti persepsi masyarakat terhadap pemakai pakaian gamis masih memberikan nilai yang positif dan sedikit bukan suatu budaya dari ne geri-negeri Islam. Seandainya gamis dikaitkan dengan gaya hidup maka masih banyak hal yang yang harus dibenahi dan diperbaiki, karena banyak juga orang yang belum paham dengan pakaian gamis.

Persepsi masyarakat merupakan suatu pendapat atas penilaian terhadap masyarakat lain sedangkan pemakai pakaian gamis adalah sebagai objek penilaian masyarakat, secara umum bahwa penilaian masyarakat terhadap pemakai pakaian gamis adalah suatu wujud perhatian masyarakat terhadap sistem sosial yang terjadi.

\section{SIMPULAN}

Dari hasil penemuan dan pembahasan dan berdasarkan uraian-uraian yang telah ditemukan serta hasil dari analisis, maka dapat disimpulkan bahwa persepsi masyarakat terhadap pemakai pakaian gamis sangat positif. Pakaian gamis adalah pakaian sunnah yang diajarkan Rasulullah dan yang kemudian dicontohkan oleh para sahabat Nabi. Masyarakat 
DOI: $10.30596 /$ persepsi.v\% vi\% i.4484

mengetahui para pemakai pakaian gamis hal ini dengan semangkin banyaknya pemakai pakaian gamis, serta masyarakat mengetahui pemakai pakaian gamis sejak dua ribuan yang lalu.

Melalui perhatian dan pengamatan masyarakat bahwa pemakai pakaian gamis identik dengan kelemah lembutan dan pemakainya rajin shalat di masjid secara berjamaah. Masyarakat menilai para pemakai pakaian gamis tidak hanya sebatas gaya dalam berpakaian tetapi pemakai pakaian gamis sebagai ciri ketaqwaan dan keimanan seseorang. Masyarakat menilai para pemakai pakaian gamis selalu menunjukan kesopanan santunan dalam bertingkah laku dan bergaul dalam masyarakat. Pemakai pakaian gamis adalah orang-orang yang mempunyai pekerjaan yang sama seperti masyarakat secara umum.

\section{DAFTAR PUSTAKA}

Cangara, Hapied 2004 :Pengantar Ilmu Komunikasi. Jakarta : Raja Grafindo Persada Hamid \&Budianlozall : Ilmu Komunikasi Sekarang Dan Tantangan Masa Depan.

Jakarta: Kencana Prenada Media Group.

Hardjana, Agus M. 2007: Komunikasi Intrapersonal Dan Interpersonal. Kasinius Yogyakarta.

Hardjana, Andre 2000 : Audit Komunikasi. Jakarta : PT. Grasindo

Liliweri Alo 1997: Komunikasi Antar Pribadi. Bandung : Citra Aditya Bakti

Morrisan. 2013. Teori Komunikasi Individu Hingga Massa.Jakarta:Kharisma Putra Utama.

Masyhurah. 2000 :Koreksi Total Ritual Sholat. Jakarta: Pustaka Azzam.

Mulyana, Dedi.2011. Ilmu Komunikasi Suatu Pengantar. PT. Remaja Rosdakarya Bandung.

Morrisan, Wardhany 2009 : Teori Komunikasi : Bogor : Ghalia Indonesia 2010 : Teori Komunikasi Massa. Bogor : PT. Ghalia Indonesia

M.Reuby, Mahyuzar. 2010 : Memahami Komunikasi Antara Budaya. Bandung : Unpad Press Nawawi, 1987: Metode Penelitian Bidang Sosial. Jakarta : Univesitas Gadjah Mada.

Rahmat Jalaluddin, 2001, Metode Penelitian Komunikasi, Bandung. PT. Remaja Rosdakarya. Syukur, Kholil 2011.Teori Komunikasi Massa. Bandung: Cita Pustaka Media Perintis.

Syam, Nina. 2011: Psikologi Sebagai Akar Ilmu Komunikasi. Bandung: Remaja Rosdakarya. Sinulingga 2011 : Metode Penelitian. Medan : USU Press.

Supropto, Toming 2008 : Kosep-konsep Dasar Komunikasi Efektif. Yogyakarta : Med Press Walgito, Bima, 2004 : Pengantar Psikologi Umum. Yogyakarta : CV. Andi Offset.2004.

Abdul Rahmad Agus 2013 : Psikologis Sosial, Jakarta : PT. Raja Grafindo Persada Bajari Atwar, 2011 : Komunikasi Konstekstual, Bandung : PT. Remaja Rosdakarya Offset Ranjabar, Jacobus, 2006 : Sistem Sosial Budaya Indonesia (Suatu Pengantar), Bogor : Ghalia Indonesia. 